\title{
Classifiers in Yurok, Wiyot, and Algonquian
}

\author{
LISA CONATHAN \\ University of California, Berkeley
}

\section{Introduction and the Typology of Nominal Classification}

Wiyot and Yurok, Algic languages of northwestern California, have a complex system of classifiers in which a classificatory morpheme delimits the properties (primarily shape) of arguments of numerals and verbs. ${ }^{1}$ These morphemes also show up in nominal morphology, on nouns with verbal roots. The classificatory system of Yurok has been described in Robins' (1958) grammar and in Haas' (1967) article "Language and taxonomy in northwestern California." Wiyot classifiers are described in Reichard's (1925) grammar, and to a lesser extent in Teeter's (1964) grammar. Teeter worked with the last native speaker of Wiyot, who did not use many of the classifiers. In this paper I expand on these descriptions and compare the classifiers of Wiyot and Yurok to each other and to those of Algonquian languages. Classifiers in Wiyot and Yurok are clearly comparable to Algonquian classificatory medials. I also discuss how the Algic classifiers fit into the typology of classifiers proposed by Aikhenvald (2000).

I hope to clarify and correct some statements that have been made about Yurok and Wiyot in the literature on classifiers by showing that these classifiers occur on verbs other than numerals, that is, they are not only numeral classifiers, and that Wiyot has as extensive a system of classifiers as Yurok does.

In (1) I give some basic data that illustrate the phenomenon of classifiers. The data show the verb roots 'to be big' in Wiyot and 'to be black' Yurok, with different classificatory suffixes that indicate the shape or animacy of the subject of the verb. As is usual with classificatory morphemes, they classify the subject of intransitive verbs, and the object of transitive verbs.

$$
\begin{array}{ll}
\text { WIYOT } & (\text { T\&N 1993) })^{2} \\
\text { dotapł } & \text { 'be a big hairlike object' } \\
\text { dotatk } & \text { 'be a big round object' } \\
\text { dotok } & \text { 'be a big long object' }
\end{array}
$$

$$
\begin{array}{ll}
\text { YUROK } & \text { (R 1958, lexicon) } \\
\text { lo'oge'ron- 'be a black straight object' } \\
\text { lr'rgrh } & \text { 'be a black round object' } \\
\text { lr'rgry- } & \text { 'be a black animal or bird' }
\end{array}
$$

\footnotetext{
${ }^{1}$ Note that numerals are morphologically verbs.

${ }^{2}$ Abbreviations of data sources are as follows: $\mathrm{S} / \mathrm{B}=$ Berman, ed.; $\mathrm{P}=$ Proulx; $\mathrm{H}=$ Haas; $\mathrm{S}=$ Sapir; $\mathrm{K}=$ Kroeber; $\mathrm{T}=$ Teeter; $\mathrm{R}=$ Reichard; $\mathrm{T} \& \mathrm{~N}=$ Teeter and Nichols.
} 
In (2) I give some relevant information from Aikhenvald's recent typology of noun categorization. Classifiers associated with numerals are usually referred to as numeral classifiers, and Aikhenvald considers the classifiers of Yurok and Wiyot to fall into this category (2000:123), as does Mithun (1999).

\begin{abstract}
Aikhenvald's (2000) typology of Noun Categorization Devices
"Numeral classifiers...are realized outside the noun in a numeral NP, and/or in expressions of quantity. Numeral classifiers can be free forms, or affixes, typically to the numeral or quantifier. They refer to the noun in terms of its inherent properties" (Aikhenvald 2000:17).

Verbal classifiers "appear on the verb, categorizing the referent of its argument in terms of its shape, consistency, size, structure, position, and animacy" (Aikhenvald 2000:149).
\end{abstract}

Labeling these classifiers numeral classifiers, however, ignores their productive and prevalent usage on verbs. Aikhenvald has a separate category of verbal classifiers, which includes all classification strategies associated with verbs. She names three sub-types of verbal classifiers: classificatory noun incorporation, classificatory verbal affixes, and suppletive classificatory verbs.

When explaining the different morphological types of verbal classifiers, Aikhenvald cites data from the Algonquian language Ojibwe as an example of classificatory verbs. The data cited in Aikhenvald (2000) is reproduced in (3).

\author{
Ojibwe classifiers \\ sak-īk-inān \\ sakit-āpī-ssin \\ kotako-minak-ipitōn \\ kotako-minak-issē
}

\author{
'to hold on to something sheet-like' \\ 'be sticking out (string-like object)' \\ 'to roll over something round-like' \\ 'something round-like rolls over'
}

(Denny 1979:107, as cited in Aikhenvald 2000:155)

As in the California Algic languages, classifiers in Ojibwe and other Algonquian languages are distinct morphemes that appear on numerals and verbs (data from numerals is not shown here). The affixes in (3) classify the intransitive subject and transitive object as 'sheet-like', 'string-like', or 'round'. Due to their distribution on numerals and verbs, these classifiers are better termed simply classificatory affixes.

Compare the Ojibwe data in (3) to the suppletive verbs in Mescalero Apache (Athapaskan), shown in (4). In Mescalero Apache, there are sets of suppletive verbs that classify their $\mathrm{S}$ or $\mathrm{O}$ argument. There are categories for round objects, long flexible objects and long rigid objects. 


\section{Lisa Conathan}

(4)

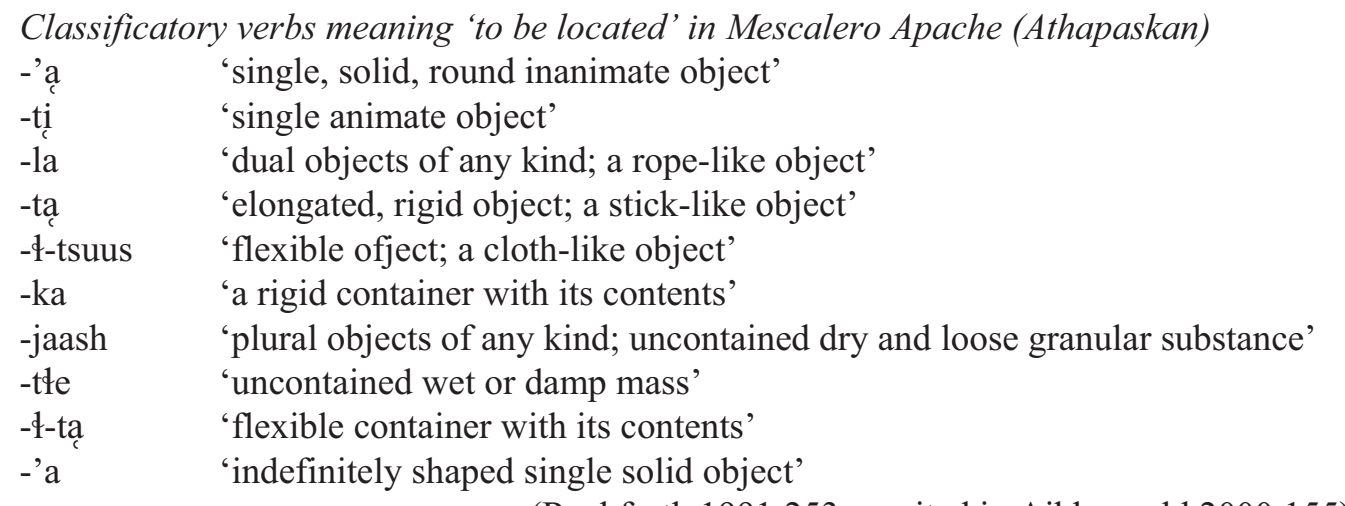

(Rushforth 1991:253, as cited in Aikhenvald 2000:155)

Categorizing Ojibwe and Mescalero Apache together as classificatory verbs both obscures the similarity of Algonquian verbal and numeral classifiers, and obscures the difference between the morphology of verbal affixation in Algonquian and suppletion in Athapaskan. In Aikhenvald's typology, both the California Algic languages and Algonquian languages were categorized in a way that obscures the similarity of their classificatory systems.

The classifiers of Yurok and Wiyot have properties both of prototypical numeral classifiers and of prototypical verbal classifiers. This should not be surprising, considering that numerals in these languages are morphologically verbs (Robins 1985), but it creates a classifier system that is not easily categorized in a typology that relies on distinguishing nouns, numerals, and verbs.

The remainder of this paper is structured as follows. In $\S 1 \mathrm{I}$ describe the attested classifiers in Wiyot and Yurok; in \$2 I discuss their distribution on numerals, verbs, and nouns derived from verbal roots; and in $\S 3$ I very briefly compare the morphology and semantics of these classifiers to those in Algonquian languages.

\section{Classifiers in Wiyot and Yurok}

In (5) and (6) are lists of Wiyot and Yurok classifiers, though this is surely still a partial list. There are about 25 classifiers in each language, although a few of them are sound symbolic variants of the same morpheme. 


\section{Classifiers in Yurok, Wiyot, and Algonquian}

(5)

Wiyot classifiers ${ }^{3}$
ditad
ditatk
dicack
ditok
ditetk
dote'1
kucapł
lun
ditbeskid
ditakd
ditabotad
ditbesupo'w
kucebo'n
kucawe'n
ditbe
ditabok
ditatkatolakw
kuceyutoyagadak
ditbegalabagadak
ditbelułe'1
ditoki'war
ditawokwł
ditbisetk
kucakotil
kutkošil
ditbalagata'1
ditkłe'1
ditawakwłe'1
dotbal

(6) Yurok classifiers

'two (generic count)'
'two spherical things'
'two small spherical things'
'two long things'
'two round, flat things'
'be large (flat thing)'
'one hairlike object'
'weave (long flexible thing)'
'two pieces'
'two strips'
'two strings of dentalia'
'two measures of dentalia'
'one fathom'
'one day'
'two days'
'two days'
'two months'
'one year'
'two years'
'two years (of sea-lions)'
'two salmon, sturgeon'
'two salmon'
'two blankets'
'one tooth'
'one head'
'two deer in a herd'
'two deer lying'
'two deerskins'
'be large (buildings)'

(K ms., R 1925, T 1964)

(R 1925, T 1964)

(R 1925)

(T ms.)

(R 1925)

(R 1925)

(T 1964)

(T\&N 1993)

(T ms.)

(T ms.)

(R 1925, T ms.)

(R 1925, T ms.)

(K ms., T\&N 1993)

(T ms.)

(R 1925)

(R 1925, T\&N 1993)

(T ms.)

(T ms., K ms.)

(R 1925)

(R 1925)

(T ms.)

(T\&N 1993)

(R 1925)

(T ms.)

(T ms.)

(R 1925)

(R 1925)

(R 1925)

(R 1925, T 1964)

$\begin{array}{ll}\text { na'a'(n) } & \text { 'two (default count)' } \\ \text { nr'r'r'y } & \text { 'two animals, birds' } \\ \text { ni'iyehl } & \text { 'two human beings' } \\ \text { na'a'r } & \text { 'two straight things' } \\ \text { na'ak' } & \text { 'two long flexible things' } \\ \text { chprrnryk- } & \text { 'be long (a stream)' } \\ \text { na'ak'wo'n } & \text { 'two bushy things' } \\ \text { no'oh } & \text { 'two round things' } \\ \text { no'ok's } & \text { 'two flat things' } \\ \text { nr'rpi' } & \text { 'two pointed objects' } \\ \text { kohchekin } & \text { 'one strand' } \\ \text { kohtep' } & \text { 'one tree' } \\ \text { kaamop } & \text { 'be rough (water)' }\end{array}$

(S ms., R 1958, H ms.)

(K 1911, S ms., R 1958, H ms.)

(K 1911, S ms., R 1958)

(R 1958, H ms.)

(S ms., R 1958, H ms.)

(R 1958)

(R 1958)

(S ms., K 1911, R 1958, H ms.)

(R 1958)

(K 1911, H ms., R 1958)

(H ms.)

(R 1958, H ms.)

(R 1958)

\footnotetext{
${ }^{3}$ Note that the orthographic representation of some of these forms is questionable, since (a) some of them are attested only once, and may have been mistranscribed, and (b) some of these forms are attested only in Reichard's material, which makes the transliteration of vowels in her (nonphonemic) orthography potentially problematic.
} 


\section{Lisa Conathan}

Yurok classifiers cont.

$\begin{array}{lll}\text { na'mi } & \text { 'two times' } & \text { (K 1911, R 1958) } \\ \text { na'ay(tani) } & \text { 'two strings of dentalia' } & \text { (K 1911, S ms.) } \\ \text { na'amoy } & \text { 'two fathoms' } & \text { (K 1911) } \\ \text { na'amoyhl } & \text { 'two nights' } & \text { (K 1911, S/B) } \\ \text { na'eyn } & \text { 'two days' } & \text { (K 1911, S ms.) } \\ \text { na'apir } & \text { 'two finger joints'4 } & \text { (K 1911, R 1958) } \\ \text { na'amrysh } & \text { 'two arm's lengths' } & \text { (R 1958) } \\ \text { nrhksryhl } & \text { 'three white deerskins' } & \text { (K 1911) } \\ \text { nr'r'ryihl } & \text { 'two deerskins' } & \text { (H ms.) } \\ \text { na'ey(teli) } & \text { 'two boats' } & \text { (K 1911, R 1958, H ms.) } \\ \text { na'a'li } & \text { 'two houses' } & \text { (R 1958, H ms.) } \\ \text { nr'rh(kr') } & \text { 'two woodpecker scalps' } & \text { (K 1911, H ms.) }\end{array}$

Starting with Wiyot, the most commonly encountered classifiers designate shape, such as 'spherical thing' and 'round flat thing' and 'long thing'. Textual examples are given in (7).

$$
\begin{array}{llll}
\text { a. } & \text { buphal } & \text { kucok } & \text { bałwi'mar } \\
\text { redwood.log } & \text { one.LONG } & \text { it.floats.downriver } \\
\text { 'One redwood log floated downriver.' }
\end{array}
$$
b. to
DURATIVE suddently
kowa
INCHOATIVE fall.HAIRLIKE

'Then suddenly the seagulls start to drop down.' čukičačk

seagull

(Wiyot: T\&N, text 49:4)

There are also classifiers that indicate units, including units of measure and of time. In Wiyot there are classifiers for 'pieces', 'strips', 'fathoms', 'days', 'months', and 'years'. See (8) for an example of this type of classifier.

$$
\begin{aligned}
& \text { we'sog halabok } \\
& \text { five be.so.many.days } \\
& \text { 'It was five days' }
\end{aligned}
$$

(Wiyot: T\&N, text 75:5)

There are also more idiosyncratic categories that refer specifically to, for example, 'deerskins', 'teeth', and 'salmon', as in (9).

$$
\begin{array}{llll}
\text { to } & \text { kwis } & \text { dikwhokwł } & \text { bołak } \\
\text { DURATIVE } & \text { suddenly } & \text { three.SALMON } & \text { salmon } \\
\text { 'There may be three salmon.' } &
\end{array}
$$

(Wiyot: T\&N, text 45:6)

The Yurok categories look largely similar. There are shape-based classes such as 'long slender thing', 'flat thing', and 'round thing', as in (10).

\footnotetext{
${ }^{4}$ Length measurement for dentalium shells.
} 
(10)

$$
\begin{aligned}
& \text { nahksoh ha'aag } \\
& \text { three.ROUND rock } \\
& \text { 'three rocks' }
\end{aligned}
$$

There are classes of units such as 'fathoms', 'nights', 'arm's lengths', and 'finger joints'. A textual example is shown in (11).

$$
\begin{array}{lllll}
\text { kwusi' 'o na'amo'yhl nohl 'r'grrch ni 'ok'w } & \text { segep } \\
\text { then LOC two.NIGHTS so.long } & \text { sweathouse } & \text { LOC he.is } & \text { coyote } \\
\text { 'Then Coyote stayed in the sweathouse for two days.' } &
\end{array}
$$

(Yurok: S/B:1020)

As in Wiyot, there are also more idiosyncratic categories in Yurok such as 'woodpecker scalp', 'strings of dentalia', and 'white deerskins'. In addition to these, Yurok distinguishes two classes of animacy: - $r$ ' $r$ ' $y$ for 'animals and 'birds,' and -eyt for 'human beings' (see (12) for a textual example of the latter).

$$
\begin{aligned}
& \text { koohchi 'o 'oole'm 'uukwsoh segep wehlowoyhl k'i 'uukwsoh } \\
& \text { once LOC be.PL his.children coyote ten.HUMANS DET his.children } \\
& \text { 'One time coyote had ten children.' }
\end{aligned}
$$

(Yurok: S/B:1022)

Yurok also has categories of substance, such as 'wood' and 'water'. This type of classifier is seen in (13a), in the adverb woop 'in the middle of the river', and in verbs with the medial -op pertaining to water (13b).

$$
\begin{aligned}
& \text { a. woop niki laaychkenek'w so pulekw } \\
& \text { middle.of.river thenthey.float.along to downstream } \\
& \text { '...they were floating along downstream in the middle of the river.' }
\end{aligned}
$$
b. kaam- 'be bad' kaamop 'be rough (water)' skew- 'be good' skewop 'be calm (water)' pel- 'be big' plohp 'to flood'

(Yurok: S/B:1020)

In both Wiyot and Yurok, the classifier system is quite elaborate. This contradicts a statement made in passing in Mithun (1999:105) that the "counting system" in Yurok is more elaborate than that in Wiyot. This impression was likely based on the fact that Yurok numerals are more well-attested in published literature than Wiyot ones, not on any difference in elaboration between the classifier systems of the two languages. The elaboration of these classes in Yurok and Wiyot is similar to that found in many languages of the Pacific Northwest, for example Athapaskan and Wakashan languages (see Mithun 1999 for a discussion of classificatory systems in languages of North America).

Both Wiyot and Yurok have a generic or default category that can be used for unclassified objects, or optionally used with objects that otherwise do have a classification. In Wiyot human beings and animals are included in the default category, while in Yurok there is a separate classification for each of these. In Wiyot available sources are in agreement that the generic classifier is $-a d$, and this is the 


\section{Lisa Conathan}

classifier used in an abstract count. For Yurok there are several different attested ways of counting in the abstract. Kroeber (1911) stated that the 'human being' class was also the abstract class. Sapir (ms.) found that the $-e$ ' $n$ class was used in abstract counting. This class is labeled 'body parts, streams, utensils and clothes' in Robins (1958:88) and 'amorphous objects' in Haas (1967:359). In Haas' field notes, a third variant is attested, $-e$ ', which may be a variant of $-e$ ' $n$. These three variants are shown in (14).

\begin{tabular}{llll}
\multicolumn{2}{c}{ Yurok generic count numerals } & from three sources & \\
& (K 1911:423) & (S ms.) & (H ms. [1950]) \\
1 & koorew & koora' & ko'r \\
2 & ni'ihl & na'a'n & na'a' \\
3 & nahkseyhl & nahkse'n & nahkse' \\
4 & choonehl & choone'n & cho'one'
\end{tabular}

In Wiyot and Yurok, as is common cross-linguistically, the use of classifiers is not obligatory on numerals (see (15)), and one can find examples where the default category is used where one might expect a classifier.

$$
\text { na'a'n or na'amoyhl 'two days' }
$$

It is also possible to find instances of the same noun being used with different classifiers, to impose different meanings, as in (16).

$$
\begin{aligned}
& \text { a. koht-ek'wo'n chiishep } \\
& \text { one-BUSHY flower } \\
& \text { 'one flower bush' }
\end{aligned}
$$
b. koht-oh we-chiishep one-ROUND 3-flower 'one flower'

(Yurok: H 1967)

While the classes distinguished by Wiyot and Yurok are similar in many respects, they also have differences in their semantics, and some of these differences are shown in (17).

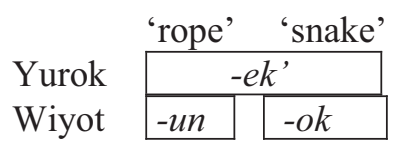

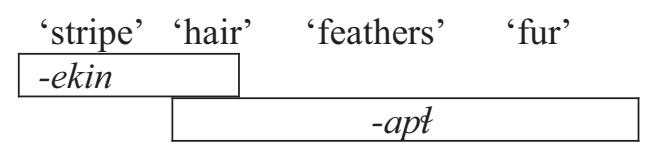

Both Wiyot and Yurok have 'long flexible object' classes that include rope and string, $-e k$ ' in Yurok and -un in Wiyot. In Yurok, snakes are generally included in this category, while in Wiyot, snakes are considered 'long objects', classified with -ok, which does not make reference to flexibility. (The classifier -ok is used for long rigid things and long flexible things.) In Wiyot, there is a 'hairlike' class (-apt) that includes hair, seaweed, feathers, and fur. Yurok has a 'strand' class (-ekin) that includes strands of hair, lines, and stripes, but not feathery or furry things. 
The classes of animacy also differ. Wiyot does not have any classes that specifically refer to animacy, while Yurok has two classes: one for humans and one for animals and birds, shown in (18).

\begin{tabular}{|c|c|c|c|}
\hline \multirow[b]{2}{*}{ Yurok } & 'humans' & 'animals' & 'generic count' \\
\hline & $-i h l,-e y h l$ & \begin{tabular}{|l|}
$r^{\prime} r r^{\prime} y$ \\
\end{tabular} & $-e{ }^{\prime} n$ \\
\hline Wiyot & & $-a d$ & \\
\hline
\end{tabular}

In both Yurok and Wiyot, the classifier that is used for human beings derives from third person verbal inflectional morphology. For Yurok, this was pointed out in Robins (1985) and more details can be found in that article. For Wiyot, the third person suffix is the 'definite subject' marker for stative verbs. Consider the data in (19) and (20), which compares the numerals used when counting humans or counting generically to third person inflected verbs.

$$
\begin{array}{llll}
\text { (19) } \begin{array}{l}
\text { kor-' 'one person' } \\
\text { ni'iy-ehl 'two people' }
\end{array} \begin{array}{l}
\text { ma'epet-' '3 (sing.) ties it up' } \\
\text { ma'epet-ehl '3 (pl.) tie it up' }
\end{array} & \text { (Yurok: R 1958:33, 87) } \\
\text { (20) } & \begin{array}{l}
\text { kuc-ad 'one (generic count)' la'g-ad '3(sing. or pl.) is heavy' } \\
\text { rit-ad 'two (generic count)' }
\end{array}
\end{array}
$$

These classifiers differ from the others in that they are derived from inflectional morphemes, and therefore do not enter into verbal or nominal derivational morphology. If Kroeber's observation that this class is the generic one for Yurok is correct (at least for some speakers), then in both Wiyot and Yurok, there is the possibility of using numeral roots inflected for third person as a default nonclassificatory numeral.

\section{Distribution on Numerals and Verbs}

Most of the classifiers in (5) and (6) are attested on numerals, and many of them are also attested on verbs. The most common type of intransitive verb that classifiers appear on is attributive, and would be translated as an adjective in English. The examples in (1) illustrated this. Some additional intransitive verbs with classifiers are listed in (21) and (22).

$$
\begin{aligned}
& \text { Yurok intransitive verbs } \\
& \text { pel- 'be big' } \\
& \text { cheyk- 'be small' } \\
& \text { che'l- 'be dry' } \\
& \text { me'wom- 'come from' }
\end{aligned}
$$

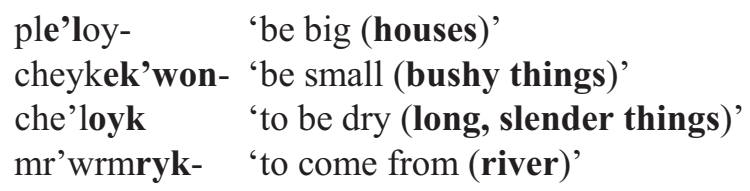

(Yurok: R 1958, lexicon) 


\section{Lisa Conathan}

(22)

Wiyot intransitive verbs
$\begin{array}{lll}\text { pal- } & \text { 'be flat' } & \text { pareck- 'be little and flat (round thing)' } \\ \text { dot- } & \text { 'be big' } & \text { dotbal- 'be big (building)' } \\ \text { baluyab- 'be white' } & \text { baluyabapt '(hairlike thing) is white' } \\ \text { parag- 'fall' } & \text { paragapt '(hairlike thing) falls' }\end{array}$

(T\&N text 65:10)

(R 1925:84)

(R 1925:84)

(T\&N text 49:4)

Classifiers also appear on transitive verbs, and in this case they classify the object of the verb. The transitive verbs with classifiers all seem to have to do with handling or manipulation, which is typical of verbal classifiers (Davidson, Elford, and Hoijer 1963). Not all verbs of handling take classifiers, and many common ones do not. Transitive verbs with classifiers are shown in (23) and (24).

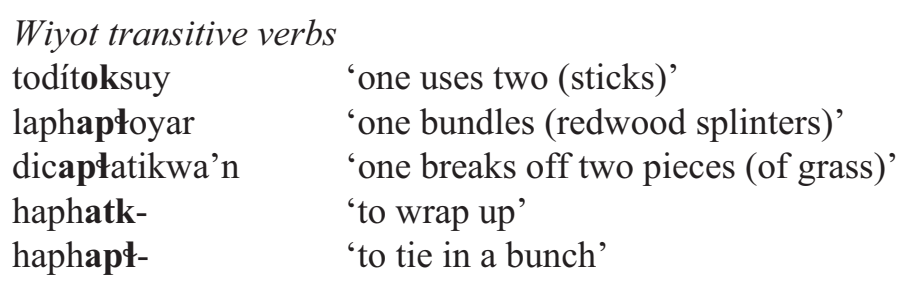

(24) Yurok transitive verbs

$\begin{array}{ll}\text { knoyket- } & \text { 'put flexible item(s) down gently,5 } \\ \text { menoyket- } & \text { 'pull something (e.g. rope)' } \\ \text { kwomhla'ret- } & \text { 'put wood (e.g. gate) up as barrier' } \\ \text { toora'ret- } & \text { 'put a stick up as a barrier' }\end{array}$

(P 1985)

Classifiers also appear on nouns derived from verbal roots. In (25) and (26) are some Wiyot and Yurok nouns with classifiers.

$$
\begin{array}{ll}
\text { Wiyot nouns } & \\
\text { hiwečk } & \text { 'money' } \\
\text { tbatkani' } & \text { 'button' } \\
\text { pitawodagatkani' } & \text { 'doorknob' }
\end{array}
$$

$$
\begin{array}{ll}
\text { Yurok nouns } & \\
\text { smota'r } & \text { 'bow' } \\
\text { laayekin } & \text { 'line, stripe' } \\
\text { knewolek } & \text { 'sea serpent' }
\end{array}
$$

(R 1958, lexicon)

The Wiyot word hiwečk 'money' contains the verbal root hiw- 'to be round'; tbatkani' 'button' is derived from a transitive verb meaning 'to pull a round thing through'; and pitawodagatkani' 'doorknob' is derived from a transitive verb meaning 'to twist a round thing by hand'. In Yurok, the noun smota' $r$ 'bow' has the classifier for 'straight things', and laayekin is composed of an initial laay, meaning 'to pass', and the classifier for 'strands, lines'.

\footnotetext{
${ }^{5}$ This is also glossed as 'leave behind more than one thing' (Berman 1982:202).
} 


\section{Algonquian}

An Algonquianist will notice the similarity between Wiyot classifiers and a set of Algonquian morphemes called classificatory medials, some of which have been reconstructed to Proto-Algonquian. J. Hewson, in his 1974 article on ProtoAlgonquian medials, remarks that some medials "appear to be remnants of an ancient system of classifiers, elements of which can still be glimpsed in the daughter languages." Many Algonquian languages have a simple numeral classifier system, in which medials attach to numeral roots and specify the shape or substance of the object being counted. As far as I know, none of the Algonquian languages has as robust a system of classifiers as Yurok and Wiyot. These classifiers also appear on verbs in Algonquian languages. Like the California Algic languages, these morphemes classify intransitive subjects and transitive objects. When the form and function of classifiers in verbal derivational morphology is compared, they look quite similar. Some data from Algonquian languages illustrate the similarity. In Wolfart's (1973) sketch of Cree, he describes these morphemes as follows:

[M]any of these [classificatory] medials denote not a specific object but a class of objects, or indeed, the characteristic features of this class... The superficial resemblance to a system of classificatory markers deserves detailed investigation. (Wolfart 1973:67)

The data in (27-29) from Algonquian languages show that these morphemes appear on attributive verbs, just as in Wiyot and Yurok.

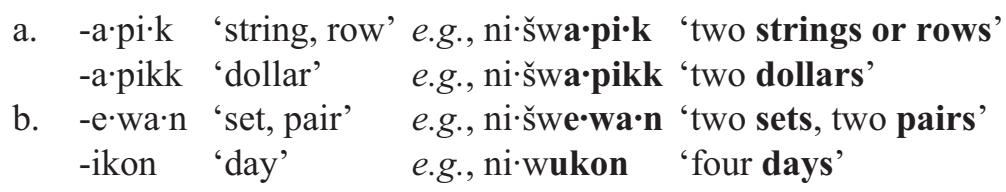

(Ojibwe: Bloomfield 1958:110-111)

(28) $\mathrm{kinwa}^{-} \cdot \mathbf{s k o s i} \cdot \mathrm{w} \quad$ 'he is long (stringlike animate object such as snake)'

kinwa-piskisi-w 'he is long (as metal or stone)'

kinwe-kan 'he is long (as cloth)'

(Cree: Bloomfield ms., cited in Hewson 1974:309)
a. -a:shku
-pishk
'made of wood'
e.g., shi:pekua:shkuan
'(the ski) is green'
-apek-
'mineral'
e.g., shi:pekua:pishkan
'(the tin cup) is green'
-ek
'thread-like'
e.g., shi:pekua:pekan
'(the shoe string) is green'
-ikam
'lying'
b. napuekaim
e.g., shi:pekuekan
'(the lawn) is green'
napueiapetshenam ' $\mathrm{s} / \mathrm{he}$ folds in two something thread-like'

(Montagnais: Cyr 1996:181)

The classifiers specify the shape of substance of the internal argument of the verb. They occur on both transitive and intransitive verbs, and at least in Montagnais and Nishnaabemwin (Ojibwe) can classify an instrumental in addition to a subject 


\section{Lisa Conathan}

or object (Cyr 1996:181, Valentine 2001). According to Aikhenvald's (2000) survey, this is unusual, since classifiers usually have scope over the direct object of a transitive verb.

\section{Conclusion}

Given the similarities between the California Algic languages and the Algonquian languages, it seems justifiable to propose that their classificatory systems are indeed cognate, and that some sort of noun classification system existed in ProtoAlgic. Classifiers are not restricted to a particular word class, and occur on numerals, verbs, and nouns. The differences between the California Algic languages and Algonquian languages are mainly in terms of the number of classifiers and their elaboration on numerals. One puzzle we are left with is why, despite the structural similarity between Wiyot and Yurok, it is so difficult to come up with cognates among the actual classifier morphemes.

\section{References}

Aikhenvald, Alexandra. 2000. Classifiers: A Typology of Noun Categorization Devices. New York: Oxford University Press.

Berman, Howard. 1982. A supplement to Robins' Yurok-English Lexicon. International Journal of American Linguistics 48:197-241.

Berman, Howard, ed. 2001. Yurok texts. In V. Golla and S. O'Neill, eds., The Collected Works of Edward Sapir XIV: Northwest California Linguistics, 1015-1038. Berlin: Mouton de Gruyter.

Bloomfield, Leonard. 1958. Eastern Ojibwa: Grammatical Sketch, Texts and Word List. Ann Arbor: University of Michigan Press.

Cyr, Danielle. 1996. Montagnais: An ethnogrammatical description. In J. Maurais, ed., Quebec's Aboriginal Languages: History, Planning, and Development, 174-203. Toronto: Multilingual Matters Ltd.

Davidson, William, L. W. Elford, and Harry Hoijer. 1963. Athapaskan classificatory verbs. Studies in the Athapaskan languages. University of California Publications in Linguistics 29:30-41. Berkeley: University of California Press.

Denny, J. P. 1979. The "Extendedness" variable in classifier semantics: Universal semantic features and cultural variation. In M. Mathiot, ed., Ethnolinguistics: Boas, Sapir and Whorf Revisited, 97-119. The Hague: Mouton.

Haas, Mary. ms. Yurok field notes (dated 1950, 1966) in the collection of the Survey of California and Other Indian Languages, University of California, Berkeley.

Haas, Mary. 1967. Language and taxonomy in Northwestern California. American Anthropologist 69:358-362.

Hewson, John. 1974. Proto-Algonquian medials. International Journal of American Linguistics 40:308-316. 
Kroeber, A. L. 1911. The languages of California north of San Francisco. University of California Publications in American Archaeology and Ethnology 9: 414-426. Berkeley: University of California Press.

Kroeber, A. L. ms. A. L. Kroeber Papers, 1869-1972. Located in the archives of the Bancroft Library, University of California, Berkeley.

Mithun, Marianne. 1999. The Languages of Native North America. Cambridge: Cambridge University Press.

Proulx, Paul. 1985. Notes on Yurok derivation. Kansas Working Papers in Linguistics 10(2):101-143.

Reichard, Gladys. 1925. Wiyot Grammar and Texts. University of California Publications in American Archaeology and Ethnology 22, 1. Berkeley: University of California Press.

Robins, R. H. 1958. The Yurok language: Grammar, texts, lexicon. University of California Publications in Linguistics 15. Berkeley: University of California Press.

Robins, R. H. 1985. Numerals as underlying verbs: The case of Yurok. In U. Pieper and G. Stickel, eds., Studia linguistica diacrhonica et synchronica Werner Winter sexagenario anno MCMLXXXIII, 723-734. Berlin: Mouton de Gruyter.

Rushforth, S. 1991. Uses of Bearlake and Mescalero (Athapaskan) classificatory verbs. International Journal of American Linguistics 57:251-266.

Sapir, Edward. ms. Yurok field notes (dated 1927) in the collection of the Survey of California and Other Indian Languages, University of California, Berkeley.

Teeter, Karl. 1964. The Wiyot language. University of California Publications in Linguistics 37. Berkeley: University of California Press.

Teeter, Karl, and John Nichols. 1993. Wiyot Handbook (two volumes). Memoirs no. 10-11. Winnipeg: Algonquian and Iroquoian Linguistics.

Valentine, J. Randolph. 2001. Nishnaabemwin Reference Grammar. Toronto: University of Toronto Press.

Wolfart, H. Christoph. 1973. Plains Cree: A grammatical study. Transactions of the American Philosophy Society 63(5):1-90.

Department of Linguistics

1203 Dwinelle Hall

University of California, Berkeley

Berkeley, CA 94720-2650

conathan@socrates.berkeley.edu 